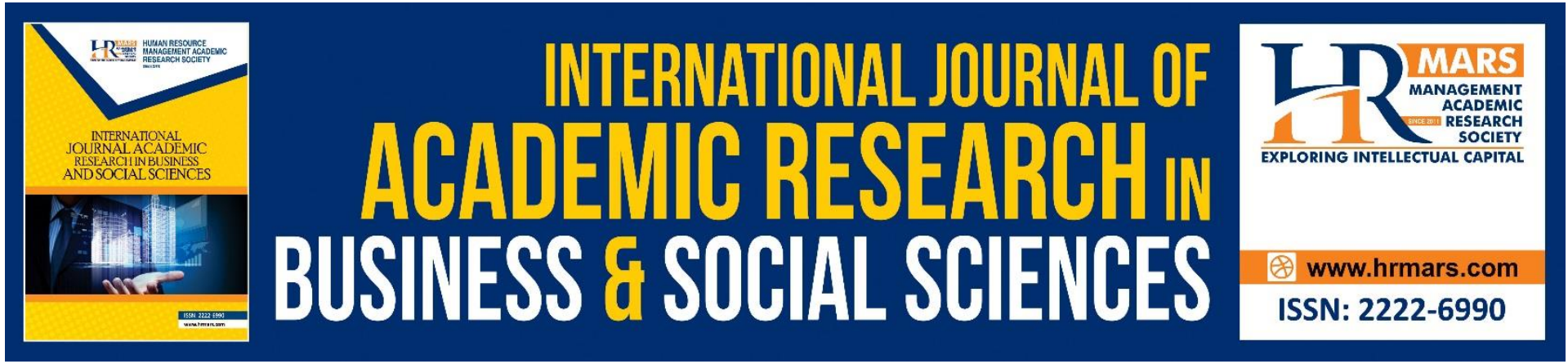

\title{
The Effect of Workload, Supervisor Support and Co-Workers Support on Work Engagement among Teachers
}

Sakinah Abd Kaiyom, Rafiduraida Abdul Rahman, Wan Salmuni Wan Mustaffa

To Link this Article: http://dx.doi.org/10.6007/IJARBSS/v11-i8/10878 DOI:10.6007/IJARBSS/v11-i8/10878

Received: 03 June 2021, Revised: 04 July 2021, Accepted: 27 July 2021

Published Online: 24 August 2021

In-Text Citation: (Kaiyom et al., 2021)

To Cite this Article: Kaiyom, S. A., Rahman, R. A., \& Mustaffa, W. S. W. (2021). The Effect of Workload, Supervisor Support and Co-Workers Support on Work Engagement among Teachers. International Journal of Academic Research in Business and Social Sciences, 11(8), 1633-1647.

Copyright: (C) 2021 The Author(s)

Published by Human Resource Management Academic Research Society (www.hrmars.com)

This article is published under the Creative Commons Attribution (CC BY 4.0) license. Anyone may reproduce, distribute, translate and create derivative works of this article (for both commercial and non-commercial purposes), subject to full attribution to the original publication and authors. The full terms of this license may be seen at: http://creativecommons.org/licences/by/4.0/legalcode

Vol. 11, No. 8, 2021, Pg. 1633 - 1647

http://hrmars.com/index.php/pages/detail/IJARBSS

JOURNAL HOMEPAGE

Full Terms \& Conditions of access and use can be found at http://hrmars.com/index.php/pages/detail/publication-ethics 


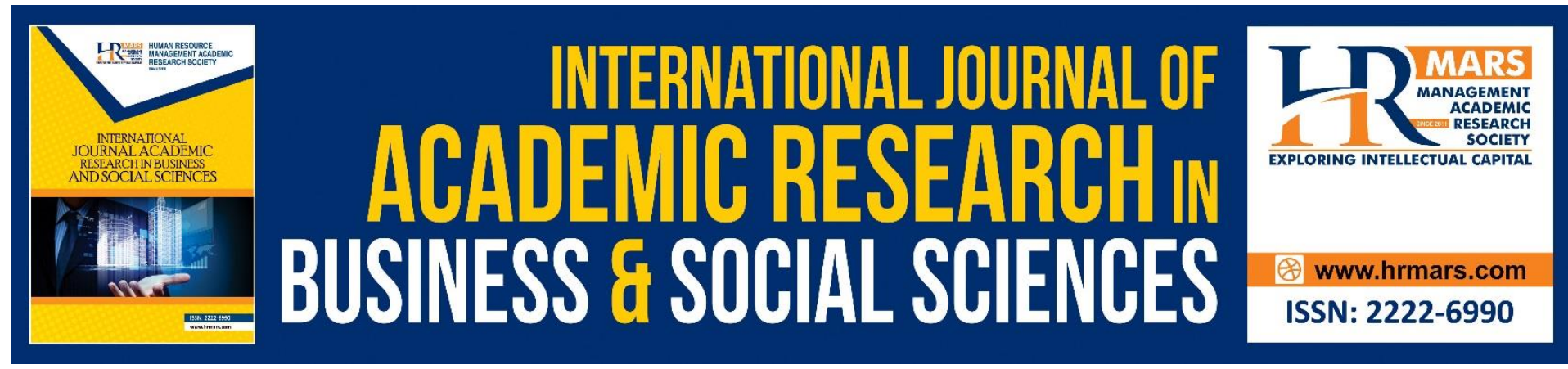

\title{
The Effect of Workload, Supervisor Support and Co-Workers Support on Work Engagement among Teachers
}

\author{
Sakinah Abd Kaiyom, Rafiduraida Abdul Rahman, Wan \\ Salmuni Wan Mustaffa \\ Faculty of Management and Economics, Sultan Idris Education University (UPSI), Tanjong \\ Malim, Perak, Malaysia \\ Email: sakinah.abdkaiyom@gmail.com
}

\begin{abstract}
This study was aimed to identify the level and the effect of workload, supervisor support and co-workers support on work engagement among boarding school teachers in Selangor. Quantitative approaches with non-experimental design were used for this study. A number of 274 teachers from boarding schools in Selangor were chosen using random sampling methods as studied samples. Research instrument involve questionnaires that was adapted and modified according to the needs and suitability of this study. Data obtained were analyzed using Statistical Package for the Social Sciences (SPSS) version 23 and descriptive statistical analysis was conducted to explain the level of workload, supervisor support, coworkers support and work engagement. Inferential statistical analysis is also implemented and involves multiple regression analysis that describes the impact of workload, supervisor support and co-workers support on work engagement. The result showed that the level of workload was moderate, while the level of supervisor support, co-workers support and work engagement were high. The findings of the study also revealed that there were a significant effect between workload ( $\beta=.149, p<.05)$, supervisor support $(\beta=.184, p<.05)$, co-workers support $(\beta=.461, p<.05)$ on teachers' work engagement. Implication from this study, school management can utilize the views of teachers on the aspects studied and make the information as a useful tool to further increase work engagement among teachers.
\end{abstract}

Keywords: Work Engagement, Workload, Supervisor Support, Co-Workers Support, Teachers

\section{Introduction}

Teachers are regarded as important agents in conveying quality education to students. Teachers also contribute to the development of high quality education and human capital to the country (Isa, Singh \& Hashim, 2018). However, a study conducted by the Academy of Higher Education Leadership (AKEPT) on the teaching of teachers in 41 schools showed that 50 percent of the teaching sessions presented unsatisfactory level, while, 12 percent of teaching sessions used best pedagogical practices and achieve high standards (Ministry of Education Malaysia, 2013). The findings show that the quality of teaching delivered by 
teachers is at a low level. Therefore, the task of a teacher to teach students has great importance. Through the lessons delivered by the teacher, it can help to build a good personality and also convey knowledge to the students.

However, the increase in workload causes teachers to work overtime at school or still be involved with work after working hours. Furthermore, technological advances, such as email, telegram, whatsapp and so on can connect and engage teachers with work during their personal time. Nowadays, teachers not only act as educators to spread their knowledge, but they also act as managers, planners, facilitators and also become a role model to the local community (Johari, Yean \& Zulkarnain, 2018). These will raise various problems, such as job dissatisfaction, stress, reduced engagement and others (Anila \& Krishnaveni, 2016) and indirectly affect their work and career development. After working hours at school, teachers need to complete all assignments for the next day while at home, in addition to controlling student learning records and attending various meeting and courses at school (Bhandare \& Seethalexmy, 2017). This can lead to unwanted results such as lack of focus in teaching and indirectly it can adversely affect student achievement and the quality of their work performance (Johari et. al., 2018).

Teachers are often faced with interpersonal processes while in school. This is due to the working environment that requires constant interaction with other teachers, students and even parents (Masluk, Santos, Cartagena, Martinez, Peck \& Leiter, 2018). The interpersonal process does not only occur while at school, but, it also occurs when teachers are at home. This is because teachers still need to interact with co-workers, students and even parents to convey certain things. This can cause teachers to be less interested in engaging in the tasks assigned to them because it can cause them to face physical and mental fatigue after a day of work. However, according to Harun et al (2015), the increasing workload is not necessarily burdensome and has a negative impact on teachers, instead there are teachers who can adapt to the work faced and further improve their work engagement in school. According to Granziera, Collie and Martin (2021), the workload borne by teachers is not entirely negative. This is because every challenge and problem faced by teachers can be solved by them through various way. This proves that the teachers in the school are experienced teachers who are committed to the work that needs to be completed by them. They also have enough experience to carry out their duties and responsibilities while in school, especially related to teaching and learning. Therefore, even though the teachers are facing a heavy workload, it does not affect their work performance in school.

Besides, principals who act as supervisors to teachers in schools should play their role as a point of reference for teachers. According to Siron et al (2017), supervisor support is one of the important factors for school development and also the morale of teachers. In addition, if the supervisor gives support and cooperation to the teachers, the matter can provide motivation, encourage participation in work, build confidence and trust. Moreover, supervisors should also play a role in understanding the problems of teachers and provide guidance if they have problems to complete the tasks that need to be performed. Every assignment given to teachers requires the support and guidance from their supervisors, in addition to showing that they are confident that all teachers are capable to do the work assigned. Alzyoud, Othman and Isa (2015) stated that it is very difficult to ensure that every employee is always engaged with their work because it is not an easy task. However, supervisors can influence every employee because they have the power to influence the workplace situation. 
In addition to the support of supervisors, the support of co-workers is also an important factor to help address the problems that exist among teachers (Vera, Martinez, Lorente \& Chambel, 2016). Co-workers support is also seen as an important factor because co-workers are able to provide assistance when one of them needs it and indirectly it is able to increase confidence that their work goals will be achieved. The importance of co-workers support is also emphasized in the Malaysia Education Blueprint 2013-2025 (MEB 2013-2025). Based on MEB 2013-2025, co-workers support can help improve the professional excellence of teachers through mentoring, development and sharing, indirectly it can increase the responsibility of co-workers in meeting the standards of the teaching profession (Ministry of Education Malaysia, 2013).

Teachers who receive support from co-workers will be more confident and feel appreciated. This can indirectly increase the level of work engagement of teachers in schools. According to Robbins and Judge (2019), work engagement can be seen in every employee if they have the opportunity to learn something new, consider the work done is important and meaningful and feel that good relationships with co-workers and supervisors will be rewarding to themselves. Mutually supportive co-workers will help teachers to share experiences, problems, teaching methods, student management strategies and so on (Avanzi et. al., 2018). Next, it helps to reduce fatigue, overcome stress and increase work engagement among teachers. Therefore, supervisors and colleagues play an important role in providing support and cooperation to teachers to carry out their duties.

Other than that, researcher founds that most studies in Malaysia did not examine workload, supervisor support, co-workers support and work engagement simultaneously, especially in the education sector. Most researchers study these variables separately. The studies that have been implemented are more focused on the workers in hotels and hospitals. This can be proven through studies conducted by Suan and Nasurdin (2016); Choo (2017); Ahmed et al (2017) and Nasurdin, Tan and Khan (2018). Due to the gap in the literature, this study aims to identify the level and the effect of workload, supervisor support and co-workers support on work engagement among boarding school teachers in Selangor.

\section{Review of Literature}

According to Schaufeli, Martinez, Pinto, Salanova, and Bakker (2002), work engagement is defined as a state of mind that leads to positive work that characterized by vigor, dedication and absorption. Vigor is characterized as a high level of energy and mental resilience while working and a willingness to invest effort in work as well as perseverance in the face of difficulties. Dedication refers to a person's engagement in work and feeling that they are important, enthusiastic, inspired, proud, and able to face challenges. On the other hand, absorption is a concentration and excitement in the job, where employee's focus is fully focused on the job (Schaufeli, Martinez, Pinto, Salanova \& Bakker, 2002). Amin, Khattak and Khan (2018) stated that work engagement is the ability and willingness of teachers to lead their organizations towards success by engaging in different work activities.

A theory that is related to this study is Social Exchange Theory (SET) (Saks, 2006). This theory described about employees who respond to a variety of psychological and environmental conditions with different levels of engagement. SET suggests that obligation is created through interactions between individuals that show progress in their relationship over time and become a trustworthy commitment (Ganzach, Pazy, Ohayun \& Brainin, 2002). The obligations only occur when individuals follow exchange rules that involve reciprocal processes (Kular, Gatenby, Rees, Soane \& Truss, 2008; Saks, 2006). In the workplace, a 
reciprocal process occurs when an employee reimburses resources provided by a supervisor by choosing to engage in a given job (Saks, 2006). High-quality exchange relationships between supervisors and employees create an obligation for employees to respond in positive and beneficial ways to reduce feelings of indebtedness to supervisors (Settoon, Bennett \& Liden, 1996; Whitener, Brodt, Korsgaard \& Werner, 1998). Employees who have a close relationship with co-workers also tend to negotiate the tasks and responsibilities that need to be performed in the workplace so that they can help each other in giving ideas, opinions, sharing expertise and knowledge as well as dealing with workload problems faced by each workers (Cropanzano \& Mitchell, 2005).

Job Demand-Resources (JD-R) model is a model of work engagement that used in this study and was developed by Bakker and Demerouti (2007). The JD-R model was developed to clarify why the employees keep engaged with work even they are faced with a high workload. These models are classified into two main categories, namely job demands and job resources. Job demand refers to workload, while job resources covers supervisor support and coworkers support. When job demand is high, then, job resources will become more prominent and can increase employee motivation in the workplace (Bakker \& Demerouti, 2007). Based on this model, support by supervisor and co-workers leads to positive engagement and work outcomes among employees (Schaufeli \& Bakker, 2004). According to Bakker, Demerouti, Hakanen and Xanthopoulou (2007), the negative relationship between workload and work engagement can be weakened if employees enjoy high support from supervisor and coworkers in the organization. According to Saks (2011), when supervisor and co-workers support in an organization increase, the work engagement of employees will also increase. This is because employees tend to reciprocate the support they receive from supervisor and co-workers through high work engagement. This is in line with SET theory, where employees will go through a reciprocal process after they receive high support from supervisors and coworkers because they want to reciprocate the support received by engaging in the work that needs to be done.

Workload refers to all tasks, responsibilities or activities that involve a teacher's time either in school or outside of school hours. Ahmed, Shah, Siddiqui, Shah, Dahri and Qureshi (2017) stated that a high workload will reduce the positive relationship of employees with the work that needs to be done as well as reduce employee motivation to work. This issue has resulted in reduced employee engagement. Antin and Kiflee (2018) stated that if the workload is too light, it will cause teachers to feel bored because they perform the same work routine every day, while, too heavy a workload will result in teachers being less motivated to perform the work and feel burdened. Nevertheless, Teng, Hassan, Kasa, Bandar, Ahmad and Nor (2017) stated that if employees have a high workload, they will always be engaged to perform the work that needs to be performed. This explains that workload has a positive effect on work engagement. The results of a study conducted by Ishak and Rusman (2018) showed that teachers in schools can manage the workload they face efficiently and their work performance is not affected by the workload, indirectly they are engaged with their work and face the burdens (Breevaart \& Bakker, 2018). The results of the study are in line with the findings of a study conducted by Katariina, Lauri and Kirsti (2019) and Zahrah, Aziz and Hamid (2019) who stated that teachers in schools are very committed and always engaged with the works that needs to be done, even if they face workload and challenges while at work. Arshad and Mustapha (2017) described workload as one of a factor that increase the effectiveness and job satisfaction among teachers and in turn increase their work engagement. 
Supervisor support in this study refers to the principal in a school. As a supervisor, the practice of work engagement among employees should be inculcated and prevent hard work among employees so that they are not overly stressed while performing the work that needs to be completed. Based on a statement by Sawasdee, Saengchai and Jermsittiparsert (2020), trained employees will be more motivated to get engaged with their work. This is in line with the statement by Park, Hye-Seung and Eun-Jee (2018) who stated that organizations can provide more professional training and development opportunities to meet the needs of employees if they get support and information from supervisors. The study conducted by Contreras, Abid, Govers and Elahi (2020) has supported the findings of the study of Ahmed, Ahmad and Jaaffar (2017); Mohamed and Ali (2016) which showed that supervisor support has a positive impact on work engagement. The findings of the study revealed that employees who have a harmonious relationship with supervisors will be motivated to perform and engage with tasks in the workplace (Shahid, Amdan, Alwi, Azmi \& Hassan, 2016). The positive influence of supervisor support can open up opportunities for employees to enhance professional development, while being able to deal with critical situations more efficiently and effectively with the co-workers.

Pimploi et al (2020) and Orgambidez-Ramos and Almeida (2017) stated that co-workers support is able to increase the work engagement of employees. The support can make an employee to be a dedicated and enthusiastic person while at work. The statement is supported by Srimarut and Mekhum (2020) who stated that positive co-worker attitudes are closely linked to higher job satisfaction. This is because support from co-workers can help employees to reduce the feeling of fatigue while working and they feel more confident while at work. Indirectly, employees will be satisfied and engaged with the work that needs to be performed. This can be proven through a study conducted by Ahmed, Majid, Al-Aali and Mozammel (2018) and Dogru (2018) which showed that there is a positive relationship between co-workers support with work engagement. According to Vera, Martinez, Lorente and Chambel (2016), if teachers receive high co-workers support in the workplace, they will feel safer and more courageous to make a decisions. Overall, the researchers concluded that co-workers support were able to increase work engagement and provide the best possible understanding for employees to understand work engagement.

\section{Methodology}

The study utilized a quantitative approach using a survey design to collect information and data on workload, supervisor support and co-worker support towards work engagement among boarding school teacher in Selangor. A simple random sampling technique was used in this study. A total of 274 teachers in nine boarding schools in Selangor were involved in this research. The workload questionnaire was modified from Othman and Omar (2014), while the supervisor support questionnaire was adapted and modified from Kottke and Sharafinski (1988). Next, the co-worker support and work engagement questionnaire were adapted and modified from Hain and Francis (2004) and Schaufeli and Bakker (2004) respectively so that the questionnaire used was appropriate to the study context. There were 30 items of the questionnaire. Besides demographic section, this survey involves four section, which is workload (Cronbach's Alpha $=0.862$ ), supervisor support (Cronbach's Alpha $=0.943)$, coworker support (Cronbach's Alpha $=0.964$ ) and work engagement (Cronbach's Alpha $=0.868$ ). The high Cronbach's Alpha value indicates that all of the items used have high reliability. Thus, the items can be considered as very good items. The likert scales of the survey was ranged from 1 (strongly disagree) to 7 (strongly agree). To analyze the data obtained, descriptive and 
inference analysis were used. Descriptive analysis involves mean value to identify the level of workload, supervisor support, co-worker support and work engagement. The inference analysis that used in this study was a multiple regression test. It is used to analyze the effect of workload, supervisor support and co-worker support towards work engagement among teachers.

\section{Results and Discussions}

The results of the level of workload, supervisor support, co-worker support and work engagement according to the total of mean value is shown in table below.

Table 1 indicated the findings of the mean score and level for each items of workload. According the results, the mean score for each items is at a moderate level. The item that records the highest mean value is "I replaced the class of teachers who did not attend school" with the mean score of $(M=4.19, S D=0.786)$. The results of the data shows that the teachers are most burdened when they have to replace other teacher classes. However, they can still control the situation and understand the situation of other fellow teachers and help each other if they face personal problems or work-related matters. Therefore, their level of burden is at a moderate level only because the teachers understand the work that needs to be done and they always help each other to ensure that their work can be completed according to the given period.

Table 1: Levels of Workload

\begin{tabular}{|c|l|c|c|c|}
\hline Item & Statement & Mean & SD & Level \\
\hline 1 & $\begin{array}{l}\text { I use time after school hours to prepare daily lesson } \\
\text { plans. }\end{array}$ & 3.95 & .727 & Moderate \\
\hline 2 & $\begin{array}{l}\text { I use time after school hours to review student } \\
\text { assignments and test paper. }\end{array}$ & 3.96 & .759 & Moderate \\
\hline 3 & $\begin{array}{l}\text { I use time after school hours to prepare test and } \\
\text { examination reports (entering marks in the computer } \\
\text { and making reviews of student achievement). }\end{array}$ & 4.01 & .724 & Moderate \\
\hline 4 & $\begin{array}{l}\text { I use time after school hours to provide documentation } \\
\text { related to administrative matters. }\end{array}$ & 3.98 & .734 & Moderate \\
\hline 5 & $\begin{array}{l}\text { I use time after school hours to complete the school's } \\
\text { task about administration management. }\end{array}$ & 3.95 & .686 & Moderate \\
\hline 6 & $\begin{array}{l}\text { I replaced the class of teachers who did not attend } \\
\text { school. }\end{array}$ & 4.19 & .786 & Moderate \\
\hline 7 & $\begin{array}{l}\text { I attended meetings related to administrative } \\
\text { management held after school hours. }\end{array}$ & 4.03 & .723 & Moderate \\
\hline
\end{tabular}

Note : $\mathrm{M}=$ Mean, $\mathrm{SD}=$ Standard Deviation,

Low (1.00-3.00), Moderate (3.01-5.00), High (5.01-7.00)

Table 2 shows the findings of the mean score and level for each items of supervisor support. The mean scores for Item 8 to Item 14 range from 5.12 to 5.44 . Item 11 shows the highest mean score among other items, which is 5.44. This item represents the question "My supervisor cares about my general satisfaction at work". School principals who act as supervisors for teachers provide support to them. This can be proven by the mean score test conducted by the researcher, that is, all items of supervisor support are at a high level. Overall, it can be seen that supervisors always support and encourage teachers to help them perform 
their tasks as well as complete their knowledge, while showing concern for the problems faced by teachers.

Table 2 : Levels of Supervisor Support

\begin{tabular}{|c|l|c|c|c|}
\hline Item & Statement & Mean & SD & Level \\
\hline 8 & My supervisor strongly considers my goals and values. & 5.31 & .996 & High \\
\hline 9 & My supervisor wants to know if I have any complaints. & 5.42 & .643 & High \\
\hline 10 & $\begin{array}{l}\text { My supervisor tries to make my job as interesting as } \\
\text { possible. }\end{array}$ & 5.15 & .964 & High \\
\hline 11 & $\begin{array}{l}\text { My supervisor cares about my general satisfaction at } \\
\text { work. }\end{array}$ & 5.44 & .678 & High \\
\hline 12 & My supervisor really cares about my well-being. & 5.12 & .990 & High \\
\hline 13 & My supervisor cares about my opinions. & 5.12 & .964 & High \\
\hline 14 & My supervisor takes pride in my accomplishments. & 5.43 & .672 & High \\
\hline
\end{tabular}

Note : $M=$ Mean, $S D=$ Standard Deviation,

Low (1.00-3.00), Moderate (3.01-5.00), High (5.01-7.00)

Table 3 indicates the findings of the mean score and level for each items of co-workers support. The mean score range of Item 15 to Item 21 is at between 5.59 to 6.08 . Item 21 represents the highest mean score among other items, which is 6.08 . The question for Item 21 is "I feel fortunate that I have good co-worker relationships". This means that teachers always maintain their good relationships with their co-workers. Therefore, they are always helpful and considerate of each other, in addition to engaging in school activities or assignments that have been entrusted. Overall, the mean score for the variable of co-worker support is at a high level.

Table 3 : Levels of Co-Workers Support

\begin{tabular}{|c|c|c|c|c|}
\hline Item & Statement & Mean & SD & Level \\
\hline 15 & I like spending work hours with my co-workers. & 5.59 & 1.002 & High \\
\hline 16 & My co-workers and I cooperate well with each other. & 5.90 & .932 & High \\
\hline 17 & $\begin{array}{l}\text { The more I interact with my coworkers the better I } \\
\text { enjoy my job. }\end{array}$ & 5.98 & .777 & High \\
\hline 18 & My coworkers and I interact positively on the job. & 5.93 & .923 & High \\
\hline 19 & I enjoy the time I spend on the job with my co-workers. & 5.90 & .930 & High \\
\hline 20 & I feel lucky to be working with my co-workers. & 5.93 & .925 & High \\
\hline 21 & $\begin{array}{l}\text { I feel fortunate that I have good co-worker } \\
\text { relationships. }\end{array}$ & 6.08 & .774 & High \\
\hline
\end{tabular}

Note : $\mathrm{M}=$ Mean, $\mathrm{SD}=$ Standard Deviation,

Low (1.00-3.00), Moderate (3.01-5.00), High (5.01-7.00)

Table 4 shows the findings of the mean score and level for each items of work engagement. The findings of the study show that Items 22 to Item 30 have a mean score range between 5.12 to 5.92 . A mean score of 5.92 represents Item 28 , which is the item shows the question 
"I feel happy when I am working intensely". This shows that even though the teachers work hard, they are still feel fun. The persistence of teachers in carrying out work is closely related to the workload that needs to be borne. However, the issue is not a problem for them because they are always given support and encouragement by supervisors as well as co-workers. Indirectly, teachers become more enthusiastic, willing to face challenges, feel important and also have high mental resilience. Overall, the mean score for the work engagement variable is at a high level.

Table 4 : Levels of Work Engagement

\begin{tabular}{|c|l|c|c|c|}
\hline Item & Statement & Mean & SD & Level \\
\hline 22 & At my work, I feel bursting with energy. & 5.60 & .909 & High \\
\hline 23 & At my job, I feel strong and vigorous. & 5.61 & .904 & High \\
\hline 24 & I can continue working for very long periods at a time. & 5.12 & 1.000 & High \\
\hline 25 & My job inspires me. & 5.71 & .737 & High \\
\hline 26 & I find the work that I do full of meaning and purpose. & 5.66 & .897 & High \\
\hline 27 & I am proud of the work that I do. & 5.89 & .764 & High \\
\hline 28 & I feel happy when I am working intensely. & 5.92 & .872 & High \\
\hline 29 & When I am working, I forget everything else around me. & 5.28 & .996 & High \\
\hline 30 & I am immersed in my work. & 5.26 & .995 & High \\
\hline
\end{tabular}

Note : $\mathrm{M}=$ Mean, $\mathrm{SD}=$ Standard Deviation, Low (1.00-3.00), Moderate (3.01-5.00), High (5.01-7.00)

Next, the results of the effect of workload, supervisor support and co-worker support on work engagement are shown in table below. Based on the study conducted, results from the feedback of the respondents are summarize in Table 5. The stepwise multiple regression approached was used to test the hypothesis. In the table below, co-workers support, supervisor support and workload are considered as independent variables, while the work engagement is considered as a dependent variable. This analysis was ran to examine the effect of workload, supervisor support and co-workers support on teachers work engagement. The result of regression analysis showed that the workload, supervisor support and co-workers support have a significant effect on work engagement among teachers. Based on the table below, the score of determination coefficient (R2) as .360. This means, coworkers support, supervisor support and workload are contributes to work engagement as much as .360 or 36 percent of work engagement are explained by the independent variables. The rest of 64 percent of work engagement might be influence by other factors that were not explored in this research. However, based on the literature review, the independent variables that studied in this research was the main predictor on work engagement. This model contributed 36 percent, which is the co-workers support is the key predictor on work engagement $(\beta=.461, t=8.597$ and $p<.05)$ that contributed 31.3 percent. Supervisor support is the second predictor $(\beta=.184, t=3.526$ and $p<.05)$ that contributed 2.6 percent on work engagement. The third predictor in this research is workload $(\beta=.149, t=2.975$ and $p<.05)$ that contributed 2.1 percent on work engagement. 
INTERNATIONAL JOURNAL OF ACADEMIC RESEARCH IN BUSINESS AND SOCIAL SCIENCES Vol. 11, No. 8, 2021, E-ISSN: 2222-6990 @ 2021 HRMARS

Table 5 : Summary of Regression Analysis

\begin{tabular}{|l|c|c|r|r|r|r|}
\hline $\begin{array}{l}\text { Independent } \\
\text { Variables }\end{array}$ & $\mathbf{B}$ & $\begin{array}{c}\text { Beta } \\
(\boldsymbol{\beta})\end{array}$ & $\mathbf{\Delta R}^{\mathbf{2}}$ & $\mathbf{t}$ & Sig. & \% \\
\hline $\begin{array}{l}\text { Co-Workers } \\
\text { Support }\end{array}$ & .518 & .461 & .313 & 8.597 & .000 & 31.3 \\
\hline Supervisor Support & .224 & .184 & .026 & 3.526 & .000 & 2.6 \\
\hline Workload & .261 & .149 & .021 & 2.975 & .003 & 2.1 \\
\hline
\end{tabular}

a. Dependent Variable: Work Engagement; $\mathrm{P}<.05$

\section{Discussion and Conclusions}

The main objective of the study was to investigate the level and the effects of workload, supervisor support, co-worker support on work engagement. The finding indicates that workload have a significant impact on work engagement among teachers. The findings of this study prove the workload that borne by teachers is able to increase their work engagement in school. The findings of this study are in line with the study conducted by Breevaart and Bakker (2018) who stated that although the employees have to face high workload, they are still engaged with the work and they are ready to face the burdens and challenges while at workplace. In line with the statement by Katariina, Lauri and Kirsti (2019) and Zahrah, Aziz and Hamid (2019), employees are always engaged with their work even when the workload is high. Workload is not a major factor contributing to the increase in work engagement among teachers in schools. This is because the teachers in boarding school face only a moderate level of workload in the school. Thus, the workload has a significant impact on the work engagement of teachers. These findings are in line with the study conducted by Arshad and Mustapha (2017) who explained that a moderate workload can increase the effectiveness and job satisfaction among educators, thereby increasing their work engagement while at workplace.

Next, the supervisor support is the second factor that act as predictor of teacher work engagement. The findings of the study indicate that supervisor support has a significant impact on teacher work engagement. These findings are in line with the study conducted by Contreras, Abid, Govers and Elahi (2020) who stated that supervisor support has a significant relationship with work engagement. This is because the support of the supervisor is able to increase work engagement through the existence of a harmonious relationship between the two parties, namely the supervisor and the employees. In addition, the study conducted by Ahmed, Ahmad and Jaaffar (2017) also supports the findings of this study and stated that the support of supervisors provide positive impact on work engagement. A good relationship between supervisor and employee will increase their engagement while at workplace. The findings of this study are also in line with Mohamed and Ali (2016) who explained that the support of supervisors has a significant relationship with work engagement. There are three things a supervisor needs to do toward teachers. Supervisor need to be willing and listen about work problems faced by the teacher, help the teacher to solve those problems and be willing to listen to the teacher's personal problems. The personal problems that shared with supervisors can make supervisors more understand the situation and difficulties that are being faced by teachers (Shahid et al., 2016). Therefore, teachers who face problems while at work can use supervisors as their reference.

Co-worker support is a key predictor of teacher work engagement and has a significant impact. The findings of this study are in line with a study conducted by Dogru (2018) and Ahmed, Majid, Al-Aali and Mozammel (2018) who stated that co-worker support has a 
positive relationship on work engagement. The study by Orgambidez-Ramos and Almeida (2017) is also in line with the results of this study. Findings of the study revealed that coworker support increased work engagement among employees. The results of this study prove that co-worker support is the most important factor in increasing teacher work engagement at schools. Furthermore, the results of this study also correspond to the study that has been implemented by Pimploi et al (2020). The findings of the study revealed that co-worker support is the most influential factor on work engagement. Thus, the researchers concluded that co-worker support is very important in increasing teacher work engagement at schools. Co-workers at school can influence teachers work environment and in turn the matter will affect the attitude of teachers in the workplace. The support provided by coworkers can create a positive perception among teachers about their workplace. At work, teachers will help each other and share information, opinions and ideas when there are friends who have problems to perform work. This is supported by Vera, Martinez, Lorente and Chambel (2016) who stated that if co-workers give good support to teachers, they feel safe and more courageous to make any decisions. This is because the support provided by coworkers can help each other to reduce the feeling of fatigue while working, in addition to employees will feel more confident and strive to engage with the work that needs to be done. In this regard, teachers are able to manage the workload that needs to be borne more easily through the support provided by their co-workers.

Given this juncture, this study has strengthened the existing Theory of Social Exchange (SET) because this study has proven the importance of workload, supervisor support and coworkers support as predictors to increase work engagement among teachers in schools. SET was used in this study to improve understanding of workload, supervisor support, co-workers support on work engagement. However, past studies using this theory are mostly implemented in Western countries, such as the studies conducted by Park, Hye-Seung and Eun-Jee (2018); Srimarut and Mekhum (2020) as well as Pimploi, Patsara, Li and Aongart ( 2020). Studies conducted using this theory in Malaysia are very few compared to Western countries, such as Osman et al (2016); Zahrah, Aziz and Hamid (2019); Makera, Nasidi, Kamaruddeen and Jemaku (2019). Therefore, the findings of this study can contribute to the context of the study in Malaysia as well as the existing knowledge.

The findings of this study are very useful to the field of education. Through the findings of the study, supervisor need to be trained to always give support to the teachers under them. Supervisor also need to build strengths in teachers through encouragement in learning. This is in line with SET, when supervisor provide assistance or support to teachers, teachers will reciprocate that assistance through their efforts to continue and engage with the work in the school. Furthermore, the encouragement of learning by supervisor can also occur among the teachers themselves, through the sharing of knowledge, opinions, ideas and suggestions between co-workers to perform a task, including the implementation of teaching and learning sessions in schools.

Besides that, this study has several practical implication to school management and the teachers to consider to understand the workload, supervisor support and co-workers support in order to enhance their work engagement at school. School management needs to pay more attention to these aspects so that teachers can increase their commitment to improve the skills and knowledge needed to perform the work that needs to be completed. In this regard, school management needs to further strengthen the relationship with teachers through their engagement in decision making, providing appropriate channels to listen to problems and 
dissatisfaction among teachers and provide good support to teachers when they face any problems, especially related with work.

Nonetheless, this study has few limitations which focused only on three variables that can effect work engagement. Thus, further study would expand the knowledge on nature of work engagement by exploring other variables, such as role ambiguity, personal growth, turnover intention and else. The future research need to be conducted the study which includes larger samples that can give better perspectives about work engagement. This is because the respondents involve only from nine boarding schools in the state of Selangor. Besides, the result of this study might be quite different from those teacher in other areas or countries. However, this findings can provides a fundamental reference for the school management and teachers that located in other areas or countries.

\section{References}

Ahmed, S., Ahmad, F., \& Jaaffar, A. R. (2017). Employee Engagement on Employee Relations with Supervisor and Employee Performance Relationship in Developing Economy: Critical Analysis with PLS-SEM. Saudi Journal of Business and Management Studies, 2(4A), 389-398.

Ahmed, U., Majid, A. H. A., Al-Aali, L., \& Mozammel, S. (2018). Can Meaningful Work Really Moderate The Relationship between Supervisor Support, Coworker Support and Work Engagement? Management Science Letters, 9, 229-242.

Ahmed, U., Shah, M. H., Siddiqui, B. A., Shah, S. A., Dahri, A. S., \& Qureshi, M. A. (2017). Troubling Job Demands at Work: Examining the Deleterious Impact of Workload and Emotional Demands on Work Engagement. International Journal of Academic Research in Business and Social Sciences, 7(6), 96-106.

Alzyoud, A. A. Y., Othman, S. Z., \& Isa, M. F. M. (2015). Examining the Role of Job Resources on Work Engagement in the Academic Setting. Asian Social Science, 11(3), 103-110.

Amin, M., Khattak, A. Z., \& Khan, M. Z. (2018). Effects of Job Stress on Employee Engagement and Organizational Commitment: A Study on Employees of Emergency Rescue Service Rescue 1122 District Peshawar. City University Research Journal, 8(2), 200-208.

Anila, K. P., \& Krishnaveni, V. (2016). Study on the Work Life Balance: Womens' Perspective. International Research Journal of Business and Management, 9(12), 30-34.

Antin, A., \& Kiflee, D. N. A. (2018). Pengaruh Beban Tugas dan Motivasi Terhadap Keefisienan Kerja Guru Sekolah Menengah di Sabah. Malaysian Journal of Social Sciences and Humanities, 3(2), 77-84.

Arshad, Z. M., \& Mustapha, R. (2017). Hubungan antara Beban Tugas Dengan Efikasi Diri dan Kepuasan Kerja Pensyarah di Kolej Vokasional. Sains Humanika, 9(1-5), 35-43.

Avanzi, L., Fraccaroli, F., Castelli, L., Marcionetti, J., Crescentini, A., Balducci, C., \& Van Dick, R. (2018). How to Mobilize Social Support against Workload and Burnout: The Role of Organizational Identification. Teaching and Teacher Education, 69, 154-167.

Bakker, A. B., \& Demerouti, E. (2007). The Job Demands-Resources Model: State of the Art. Journal of Managerial Psychology, 22(3), 309-328.

Bakker, A. B., Demerouti, E., Hakanen, J. J., \& Xanthopoulou, D. (2007). Job Resources Boost Work Engagement, Particularly when Job Demands are High. Journal of Educational Psychology, 99(2), 274-284.

Bhandare, U. V., \& Seethalexmy, N. (2017). Challenges to Maintain Work Life Balance with Reference to Degree College Teachers of University of Mumbai. International Journal of Advanced Research and Development, 2(6), 4-7. 
Breevaart, K., \& Bakker, A. B. (2018). Daily Job Demands and Employee Work Engagement: The Role of Daily Transformational Leadership Behavior, Journal of Occupational Health Psychology, 23(3), 338-349.

Choo, L. S. (2017). Colleague Support and Role Clarity in Promoting the Work Engagement of Frontliners in Malaysian Hotels. International Society for Performance Improvement, 29(4), 389-405.

Contreras, F., Abid, G., Govers, M., \& Elahi, N. S. (2020). Influence of Support on Work Engagement in Nursing Staff: The Mediating Role of Possibilities for Professional Development. Academia Revista Latinoamericana de Administracion, 1-21.

Cropanzano, R., \& Mitchell, M. S. (2005). Social Exchange Theory: An Interdisciplinary Review. Journal of Management, 31, 874-900.

Dogru, C. (2018). The Relationship between Perceived Support and Innovative Behavior: Analyzing the Mediating Role of Work Engagement. Journal of Business Research Turk, 10(2), 384-402.

Ganzach, Y., Pazy, A., Ohayun, Y., \& Brainin, E. (2002). Social Exchange and Organizational Commitment: Decision-Making Training for Job Choice as an Alternative to the Realistic Job Preview. Personnel Psychology, 55, 613-637.

Granziera, H., Collie, R., \& Martin, A. (2021). Understanding Teacher Wellbeing through Job Demands-Resources Theory. In Mansfield, C. F. (Eds), Cultivating Teacher Resilience: International Approaches, Applications and Impact (pp. 229-244). Australia: Springer.

Hain, C. A., \& Francis, L. (2004). Development and Validation of a Coworker Relationship Scale. Unpublished thesis. Canada: Saint Mary's University.

Harun, M., Omar, Z., Idris, K., \& Basri, R. (2015). The Development and Validation of Instrument of Teacher's Workload. International Journal of Education and Research, 3(3), 401-412.

Isa, N. M., Singh, H. K. L., \& Hashim, R. (2018). Job Stress, Work-to- Family Conflict and Social Support in the Education Industry. Journal of Administrative Science, 15(3), 1-17.

Ishak, R., \& Rusman, S. N. F. (2018). Prestasi Kerja Guru dan Hubungannya dengan Faktor Beban Tugas, Persekitaran Kerja dan Personal: Kajian Kes di sebuah Sekolah di Sabah. Jurnal Kepimpinan Pendidikan, 5(1), 1-15.

Johari, J., Yean T. F., \& Zulkarnain, Z. I. T. (2018). Autonomy, Workload, Work-Life Balance and Job Performance among Teachers. International Journal of Educational Management, 32(1), 107-120.

Katariina, S. A., Lauri, H., \& Kirsti, L. (2019). Work Burnout and Engagement Profiles among Teachers. Frontiers in Psychology, 10(2254), 1-8.

Kottke, J. L., \& Sharafinski, C. E. (1988). Measuring Perceived Supervisory and Organizational Support. Educational and Psychological Measurement, 48, 1075-1079.

Kular, S., Gatenby, M., Rees, C., Soane, E., \& Truss, K. (2008). Employee Engagement: A Literature Review. UK: Kingston University.

Makera, A. U., Nasidi, Y., Kamaruddeen, A. M., \& Jemaku, I. M. (2019). Correlation between Team and Co-worker Relationship and Employee Engagement. Journal of Advanced Research in Business and Management Studies, 14(1), 16-24.

Masluk, B., Santos, S. G., Cartagena, A. A., Martinez, A. A., Peck, E., \& Leiter, M. P. (2018). Areas of Worklife Scale (AWS) Short Version (Spanish): A Confirmatory Factor Analysis based on a Secondary School Teacher Sample. Journal of Occupational Medicine and Toxicology, 13(20), 1-10. 
Ministry of Education Malaysia. (2013). Malaysia Education Blueprint 2013-2025: Preschool to Post-Secondary Education. Putrajaya: Ministry of Education Malaysia.

Mohamed, S. A., \& Ali, M. (2016). The Impact of Supervisor Support on Employees' Engagement, International Journal of Research and Review, 3(3), 14-20.

Nasurdin, A. M., Tan, C. L., \& Khan, S. N. (2018). Linking Social Support, Work Engagement and Job Performance in Nursing. International Journal of Business and Society, 19(2), 363386.

Orgambidez-Ramos, A., \& Almeida, H. D. (2017). Work Engagement, Social Support, and Job Satisfaction in Portuguese Nursing Staff: A Winning Combination. Applied Nursing Research, 36, 37-41.

Osman, I., Noordin, F., Daud, N., \& Othman, M. Z. (2016). The Dynamic Role of Social Exchange and Personality in Predicting Turnover Intentions among Professional Workers. Procedia Economics and Finance, 35, 541-552.

Othman, N., \& Omar, H. (2014). Beban Tugas dan Motivasi Pengajaran Guru di Sekolah Menengah Daerah Ranau. Jurnal Pemikir Pendidikan, 5, 35-57.

Park, S., Hye-Seung, K., \& Eun-Jee, K. (2018). Does Supervisor Support Make a Difference in Employees' Training and Job Performance? An Empirical Study of a Professional Development Program. European Journal of Training and Development, 1-34.

Pimploi, T., Patsara, S., Li, H., \& Aongart, A. (2020), The Influence of Work-Related Supports on Employee Engagement in the Pharmaceutical Industry in Thailand. Systematic Review Pharmacy, 11(2), 576-585.

Robbins, S. P., \& Judge, T. A. (2019). Organizational Behavior. United States: Pearson Education Inc.

Saks, A. M. (2006). Antecedents and Consequences of Employee Engagement. Journal of Managerial Psychology, 21(7), 600-619.

Saks, A. M. (2011). Manage Employee Engagement to Manage Performance. Industrial and Organizational Psychology, 4, 204-207.

Sawasdee, A., Saengchai, S., \& Jermsittiparsert, K. (2020). The Role of Emotional Demands, Supervisor Support and Training Opportunities towards Work Engagement among Employees in Pharmaceutical Companies of Thailand. Systematic Review Pharmacy, 11(3), 176-184.

Schaufeli, W. B., \& Bakker, A. B. (2004). Job Demands, Job Resources and Relationship with Burnout and Engagement: A Multi-Sample Study. Journal of Organizational Behavior, 25, 293-315.

Schaufeli, W. B., Martínez, I. M., Pinto, A. M., Salanova, M., \& Bakker, A. B. (2002). Burnout and Engagement in University Students. Journal of Cross-Cultural Psychology, 33(5), 464-481.

Settoon, R. P., Bennett, N., \& Liden, R. C. (1996). Social Exchange in Organizations: Perceived Organizational Support, Leader-Member Exchange, and Employee Reciprocity. Journal of Applied Psychology, 81(3), 219-227.

Shahid, S. A. M., Amdan, S., Alwi, A., Azmi, F. S., \& Hassan, C. N. (2016). Social Support, Negative Affectivity, and Work Personal Life Balance of Academics. International Journal of Social Science and Humanity, 6(7), 500-504.

Siron, R., Saad, N. M., Jamil, N., \& Tasripan, M. A. (2017). An Assessment of Green Quality of Working Life Dimensions: A Study at Public Institutions in Southern Zone State of Malaysia. International Review of Management and Business Research, 6(3), 12161228. 
Srimarut, T., \& Mekhum, W. (2020). The Influence of Workload and Co-Worker Attitude on Job Satisfaction among Employees of Pharmaceutical Industry in Bangkok, Thailand: The Mediating Role of Training. Systematic Review Pharmacy, 11(2), 603-611.

Suan, C. L., \& Nasurdin, A. M. (2016). Supervisor Support and Work Engagement of Hotel Employees in Malaysia. Gender in Management: An International Journal, 31(1), 2-18.

Teng, M., Hassan, Z., Kasa, M., Bandar, N. F. A., Ahmad, R., \& Nor, N. N. M. (2017). The Relationship between Workload and Students' Disruptive Behaviours with Turnover Intention among Academicians of Private Higher Education Institutions: Boredom at Workplace as Mediator. International Journal of Business and Society, 18(4), 828-837.

Vera, M., Martinez, I. M., Lorente, L., \& Chambel, J. M. (2016). The Role of Co-worker and Supervisor Support in the Relationship between Job Autonomy and Work Engagement among Portuguese Nurses: A Multilevel Study. Social Indicators Research, 121(3), 1-16.

Whitener, E. M., Brodt, S. E., Korsgaard, M. A., \& Werner, J. M. (1998). Managers as Initiators of Trust: An Exchange Relationship Framework for Understanding Managerial Trustworthy Behavior. Academy of Management Review, 23(3), 513-530.

Zahrah, N., Aziz, A., \& Hamid, S. N. A. (2019). Workload and Work Engagement among Nurses in Public Hospitals: Moderating Role of Religious Spirituality. International Journal of Management, Accounting and Economics, 6(4), 297-312. 